\title{
Progressive Motor Neuronopathy: A Critical Role of the Tubulin Chaperone TBCE in Axonal Tubulin Routing from the Golgi Apparatus
}

\author{
Michael K. E. Schaefer, ${ }^{1,2}$ Henning Schmalbruch, ${ }^{3}$ Emmanuelle Buhler, ${ }^{1,2}$ Catherine Lopez,${ }^{1,2}$ Natalia Martin, ${ }^{4}$ \\ Jean-Louis Guénet, ${ }^{4}$ and Georg Haase ${ }^{1,2}$ \\ ${ }^{1}$ Inserm, Unité 29, Equipe Avenir, 13273 Marseille, France, ${ }^{2}$ Aix Marseille Université, Institut de Neurobiologie de la Méditerranée, 13284 Marseille, France, \\ ${ }^{3}$ Panum Institute, University of Copenhagen, DK-2200 Copenhagen, Denmark, and ${ }^{4}$ Institut Pasteur, 75015 Paris, France
}

\begin{abstract}
Axonal degeneration represents one of the earliest pathological features in motor neuron diseases. We here studied the underlying molecular mechanisms in progressive motor neuronopathy ( $p m n)$ mice mutated in the tubulin-specific chaperone TBCE. We demonstrate that TBCE is a peripheral membrane-associated protein that accumulates at the Golgi apparatus. In pmn mice, TBCE is destabilized and disappears from the Golgi apparatus of motor neurons, and microtubules are lost in distal axons. The axonal microtubule loss proceeds retrogradely in parallel with the axonal dying back process. These degenerative changes are inhibited in a dose-dependent manner by transgenic TBCE complementation that restores TBCE expression at the Golgi apparatus. In cultured motor neurons, the pmn mutation, interference RNA-mediated TBCE depletion, and brefeldin A-mediated Golgi disruption all compromise axonal tubulin routing. We conclude that motor axons critically depend on axonal tubulin routing from the Golgi apparatus, a process that involves TBCE and possibly other tubulin chaperones.
\end{abstract}

Key words: motor neuron disease; ALS; axon degeneration; tubulin chaperone; microtubules; Golgi apparatus

\section{Introduction}

Human motor neuron diseases such as amyotrophic lateral sclerosis (ALS) and spinal muscular atrophy (SMA) are incurable and fatal disorders characterized by loss of motor neuron cell bodies, axonal degeneration, and skeletal muscle denervation (for review, see Boillee et al., 2006; Pasinelli and Brown, 2006). In several ALS and SMA mouse models, motor axonal degeneration occurs weeks to months before cell body loss and displays numerous features of a retrograde "dying back" process. In transgenic mutant superoxide dismutase 1 G93A mice, a model of familial ALS1, denervation of endplates appears at presymptomatic stage, loss of ventral root axons at disease onset, and loss of spinal motor neuron cell bodies only at end stage (Fischer et al., 2004) (see also Kennel et al., 1996a; Frey et al., 2000; Pun et al., 2006). SMA model mice deficient in neuronal SMN (survival motor neuron) display extensive muscle denervation and motor axon loss at a moment when the number of spinal motor neuron cell bodies is

\footnotetext{
Received April 10, 2007; revised May 26, 2007; accepted June 21, 2007.

This work was funded by grants from Inserm (Avenir Program), Conseil Général des Bouches du Rhône, Association Française contre les Myopathies, Fédération pour la Recherche sur le Cerveau, and the Amyotrophic Lateral Sclerosis Association. M.S. received a postdoctoral fellowship from Inserm and Deutsche Forschungsgemeinschaft (Grant DFG 1261/1-1). We thank M. Szatanek (Institut Pasteur, Paris, France) and S. Corby (Inserm, Marseille, France) for genotyping, M. Bjaerg (University of Copenhagen, Copenhagen, Denmark) for expert help in histology, and A. Andrieux and D. Job (Commissariat à l'Energie Atomique, Grenoble, France), F. Lotfi, C. Faivre-Sarrailh, and C. Raoul (Inserm, Marseille, France) for helpful discussions.

Correspondence should be addressed to Dr. Georg Haase, Institut de Neurobiologie de la Méditerranée, Equipe Avenir, 13288 Marseille cedex 09, France. E-mail: haase@inmed.univ-mrs.fr. D0I:10.1523/JNEUROSCl.1599-07.2007

Copyright $\odot 2007$ Society for Neuroscience $\quad$ 0270-6474/07/278779-11\$15.00/0
}

only modestly reduced (Cifuentes-Diaz et al., 2002). Alsin/ALS2 knock-out mice show retrograde axonal degeneration in the dorsolateral spinal cord tract but no loss of cell bodies in the motor cortex (Devon et al., 2006; Yamanaka et al., 2006). It remains unclear however whether axonal dying back is triggered in the axon itself or whether it is a consequence of degenerative changes originating in the cell body (Fischer et al., 2004; Conforti et al., 2007).

We here studied this question in mice with progressive motor neuronopathy ( $p m n)$. Homozygous pmn mice suffer from a severe motor neuron disease characterized by axonal dying back (Schmalbruch et al., 1991) and progressive loss of motor units (Kennel et al., 1996b). Axonal degeneration and clinical disease course in pmn mice can be attenuated by neurotrophic factor gene therapy (Sendtner et al., 1992; Sagot et al., 1995a; Haase et al., 1997) or expression of the axonoprotective Wld ${ }^{\mathrm{S}}$ protein (Ferri et al., 2003) but not by overexpression of the antiapoptotic protein Bcl-2 (Sagot et al., 1995b). We and others showed that pmn mice are mutated in TBCE (Bömmel et al., 2002; Martin et al., 2002), one of five tubulin-specific chaperones (TBCA-TBCE) involved in tubulin folding and dimerization (Tian et al., 1996, 1997). The pmn mutation, a tryptophan to glycine exchange at the $\mathrm{C}$ terminus of TBCE, causes axonal microtubule loss in vivo (Martin et al., 2002) and, according to Bömmel et al. (2002), also impedes motor axon growth in vitro.

We identify TBCE as a tubulin chaperone that accumulates at the cis-Golgi apparatus and demonstrate its requirement for axonal tubulin routing. In spinal motor neurons of early symptom- 
atic pmn mice, the TBCE protein is destabilized, leading to a drastic reduction in tubulin levels and microtubule densities in distal axons. Axonal microtubule loss progresses from distal to proximal, correlates with axonal degeneration, and is inhibited by transgenic TBCE protein expression. These data help to explain the axonal dying back process in pmn mice and provide a mechanistic link between motor axon maintenance and TBCE function at the Golgi apparatus.

\section{Materials and Methods}

Antibodies and reagents. Antiserum against TBCE (SA53) was generated by immunizing a rabbit with a mixture of two peptides corresponding to amino acids 87-102 and 389-402 of mouse TBCE (Eurogentec, Liege, Belgium). A second anti-TBCE antiserum (GP52) was generated against the same peptides. In control experiments, antisera were preabsorbed with antigenic peptides or recombinant green fluorescent protein (GFP)-TBCE protein (G. Haase and A. Elmarjou, unpublished observation). Antibodies and their dilutions in immunocytochemistry were as follows: TBCE (1:300), $\alpha$-tubulin (1:1000; Sigma, St. Louis, MO), $\beta_{\mathrm{III}}$-tubulin (TuJ1; 1:2000; Babco, Richmond, CA), GFP (monoclonal antibody, 1:1000; Roche, Indianapolis, IN), myelin basic protein (1:500; Chemicon, Temecula, CA), neurofilament medium chain (NN18, 1:2000; Sigma), S-100 (SH-B1, 1:1000; Sigma), and GM130, p115, Vti1a, and Vti1b (1:250; Becton Dickinson, Walton, KY). Fluorochrome- or horse radish peroxidase-conjugated secondary antibodies were from Invitrogen (Carlsbad, CA) or Jackson ImmunoResearch (West Grove, PA).

Reagents were from the following suppliers: PBS, HBSS, HAM F-10, trypsin, culture media, and supplements (Invitrogen); Hibernate E (BrainBits, Springfield, IL); DNase I, polyornithin, laminin, glial cell line-derived neurotrophic factor (GDNF), taxol, and nocodazole (Sigma), CNTF and BDNF (R \& D Systems, Minneapolis, MN), Vectashield-4',6'-diamidino-2-phenylindole (Vector Laboratories, Burlingame, CA); complete protease inhibitors and Dormicum (Roche); Hypnorm (Janssen, Beerse, Belgium); bisbenzimide and brefeldin A (BFA) (Fluka, Saint Quentin Fallavier, France); and Fluoromount (Southern Biotechnology, Birmingham, AL).

Mouse lines and genotyping. The $p m n$ mice were maintained as $+/ p m n$ mice and $X t+/+p m n$ ("Xt/pmn") mice (Brunialti et al., 1995) on a mixed background (C57BL/6; 129/SvJ) using intercrosses (more than F5). Lines of transgenic neuron-specific enolase (NSE):TBCE mice (Martin et al., 2002) were crossed with $X t / p m n$ mice and maintained as $X t /$ $p m n \mathrm{TBCE}^{\mathrm{PA} /+}$ and $\mathrm{Xt} / \mathrm{pm} n \mathrm{TBCE}^{\mathrm{PC} /+}$ stocks on the same genetic background. Thy1-yellow fluorescent protein (YFP) line 16 mice (Feng et al., 2000) were used for the analysis of TBCE localization in peripheral nerves. Mice were housed in animal facilities licensed by the French Ministry of Agriculture (agreement A 75485), and experiments were performed in strict compliance with European legislation.

Mouse genotyping was done as follows. The pmn and wild-type alleles were detected using primers 5 '-GTCTTACTGCTCCCTACTTG $(\mathrm{C} 45 \mathrm{~F})$ and $5^{\prime}$-GTGAAAACAGAAAGGGCAGAG (C45R) and 35 cycles of amplification $\left(95^{\circ} \mathrm{C}, 40 \mathrm{~s} ; 58^{\circ} \mathrm{C}, 40 \mathrm{~s} ; 72^{\circ} \mathrm{C}, 40 \mathrm{~s}\right)$, followed by DNA purification (QiaQuick; Qiagen, Hilden, Germany), $2 \mathrm{~h}$ incubation with the restriction enzyme MnlI (New England Biolabs, Ipswich, MA), and gel electrophoresis (3\% Metaphor agarose; Tebu, Le Perray en Yvelines, France). The NSE:TBCE transgene was detected by PCR using primers 5'-CCAAGGAGATCGACTCTAGAG (NSE-7F), 5'-AAGCGACTGTTCATATTC (TB-7R), 5'-GATCATGACCGCCGTAGG (X1), and 5' CATGAACTTGTCCCAGGCTT (X2), 35 cycles $\left(92^{\circ} \mathrm{C}, 40 \mathrm{~s} ; 58^{\circ} \mathrm{C}, 40 \mathrm{~s}\right.$; $\left.72^{\circ} \mathrm{C}, 1 \mathrm{~min}\right)$ and $2 \%$ agarose gel electrophoresis.

Western blots and immunohistochemistry. Tissues were dissected from deeply anesthetized mice. Proximal and distal sciatic nerve segments of 4 $\mathrm{mm}$ length were dissected out, respectively, at the hip level and the knee level. Mouse spinal cords and sciatic nerves were homogenized in lysis buffer ( $150 \mathrm{~mm} \mathrm{NaCl}, 50 \mathrm{~mm}$ Tris-HCl, 2 mm EDTA, 1\% Triton X-100, $0.1 \%$ SDS, pH 7.4, and protease inhibitors). NSC34 cells were directly lysed in Laemli's buffer, subjected to SDS-PAGE, Western blotting, incubated with antibodies, and revealed with the ECL plus system (GE
Healthcare, Little Chalfont, UK). Western blots were scanned and analyzed by densitometry (NIH ImageJ). For immunohistochemistry, deeply anesthetized mice were perfused with $4 \%$ paraformaldehyde, and spinal cords, sciatic nerves, and phrenic nerves were dissected, postfixed overnight, and cryoprotected in 30\% sucrose for $48 \mathrm{~h}$. After tissue embedding, $14 \mu \mathrm{m}$ transverse or $20 \mu \mathrm{m}$ frontal sections of the spinal cord and $10 \mu \mathrm{m}$ cross sections of nerves were cut on a cryostat and collected on glass slides. Sections were blocked, incubated overnight with primary antibodies, washed, incubated with fluorochrome-conjugated secondary antibodies, reacted with $0.1 \mu \mathrm{g} / \mathrm{ml}$ bisbenzimide, and mounted in Fluoromount.

Subcellular fractionation. Spinal cords or NSC34 cells were homogenized in buffer (50 mм Tris-HCl, pH 7.5, 2 mм EGTA, 2 mм EDTA, 5\% sucrose, $0.1 \mathrm{~mm}$ DTT, and protease inhibitors) and centrifuged at $900 \times$ $g$ for $10 \mathrm{~min}$ at $4^{\circ} \mathrm{C}$ to remove nuclei and cell debris. The postnuclear supernatant was centrifuged for $1.5 \mathrm{~h}$ at $4^{\circ} \mathrm{C}$ and $60,000 \mathrm{rpm}$ in a TLA100 rotor (Beckman Coulter, Fullerton, CA) to obtain cytosol and crude membrane fractions. The membrane pellet was dissolved in homogenization buffer containing $0.5 \%$ Triton X-100 and incubated for $1 \mathrm{~h}$ on ice. Equal volumes of subcellular fractions were subjected to SDS-PAGE and processed as outlined above.

Retrograde labeling of motor neurons. Mice were anesthetized with Hypnorm/Dormicum (fentanyl at $0.5 \mathrm{mg} / \mathrm{ml}$, fluanisone at $2.5 \mathrm{mg} / \mathrm{ml}$, and midazolam at $1.25 \mathrm{mg} / \mathrm{ml} ; 6 \mathrm{ml} / \mathrm{kg}$ body weight, s.c.). Under a stereomicroscope, a ventral incision was made on the right side of the neck, the cervical plexus was isolated, and the phrenic nerve was identified. The phrenic nerve was cut without opening the pleural cavity, and a piece of hemostatic sponge (Spongostan; Ferrosan, Soeborg, Denmark) $1 \times 1 \times$ $1 \mathrm{~mm}$ in size was soaked in 10\% Fluoro-ruby (Chemicon) in Ringer's solution with $2 \%$ DMSO, and applied to the proximal stump. Labeling by dextran tracers is restricted to cut axons (Richmond et al., 1994), and care was taken not to injure other branches of the cervical plexus or muscles innervated by it. The wound was closed in two layers with 9-0 and 6-0 sutures.

Fluorescent, light, and electron microscopy. Confocal microscopy was performed with upright or inverted LSM 510 microscopes (Zeiss, Oberkochen, Germany) using $63 \times, 40 \times$, or $10 \times$ objectives. For light and electron microscopy, glutaraldehyde-fixed nerves and roots were postfixed with osmic tetroxide and embedded in epoxy resin. For light microscopy, cross sections $3 \mu \mathrm{m}$ thick were stained with p-phenylenediamine, photographed with a $40 \times$ oil immersion objective, and printed to 1200 times. Thin cross sections for electron microscopy were stained with uranyl acetate and lead citrate. To facilitate identifying microtubules, the sections were tilted in the electron microscope (CM100; Philips, Eindhoven, The Netherlands) by means of a goniometer to obtain exact cross sections. The magnification of the microscope was calibrated against a replica of a diffraction grating $(2160$ lines $/ \mathrm{mm})$. With the aid of a digitizer tablet, all apparently intact myelinated axons were counted on light micrographs of the phrenic nerves, axonal areas were measured, and microtubules were counted on electron micrographs printed to $\sim 60,000$ times. The investigator (H.S.) was blinded with respect to the genotype of the animals.

Expression plasmids and small interference RNAs. Expression vectors for GFP-TBCE, hemagglutinin-TBCE, and FLAG-TBCE were generated by subcloning mouse wild-type TBCE cDNA using pCAGGS-GFP (Jacquier et al., 2006) or pCMV-Tag1 vectors (Stratagene, La Jolla, CA) as backbone. The GFP- $\alpha$-tubulin expression vector was generated by subcloning a fragment from pAcGFP1-tubulin (Clontech) into pCAGGS (Jacquier et al., 2006). Small interference RNAs (siRNAs) against luciferase or TBCE were from Dharmacon (Chicago, IL). Targeted regions of mouse TBCE (AY082332) were as follows: siTBCE 1, nucleotides 118-137; siTBCE 2, nucleotides 242-262; siTBCE 3, nucleotides 792-812; siTBCE 4, nucleotides 1108-1126; and siTBCE pool, equimolar mix of siTBCE $1-4$.

Cell cultures and in vitro assays. Motor neurons were prepared from embryonic day 12 spinal cords, electroporated with DNA plasmids and/or siRNAs, and cultured in the presence of the neurotrophic factors BDNF, CNTF, and GDNF (Raoul et al., 2002; Jacquier et al., 2006). For immunocytochemistry, cells were fixed by adding an equal volume of $8 \%$ 

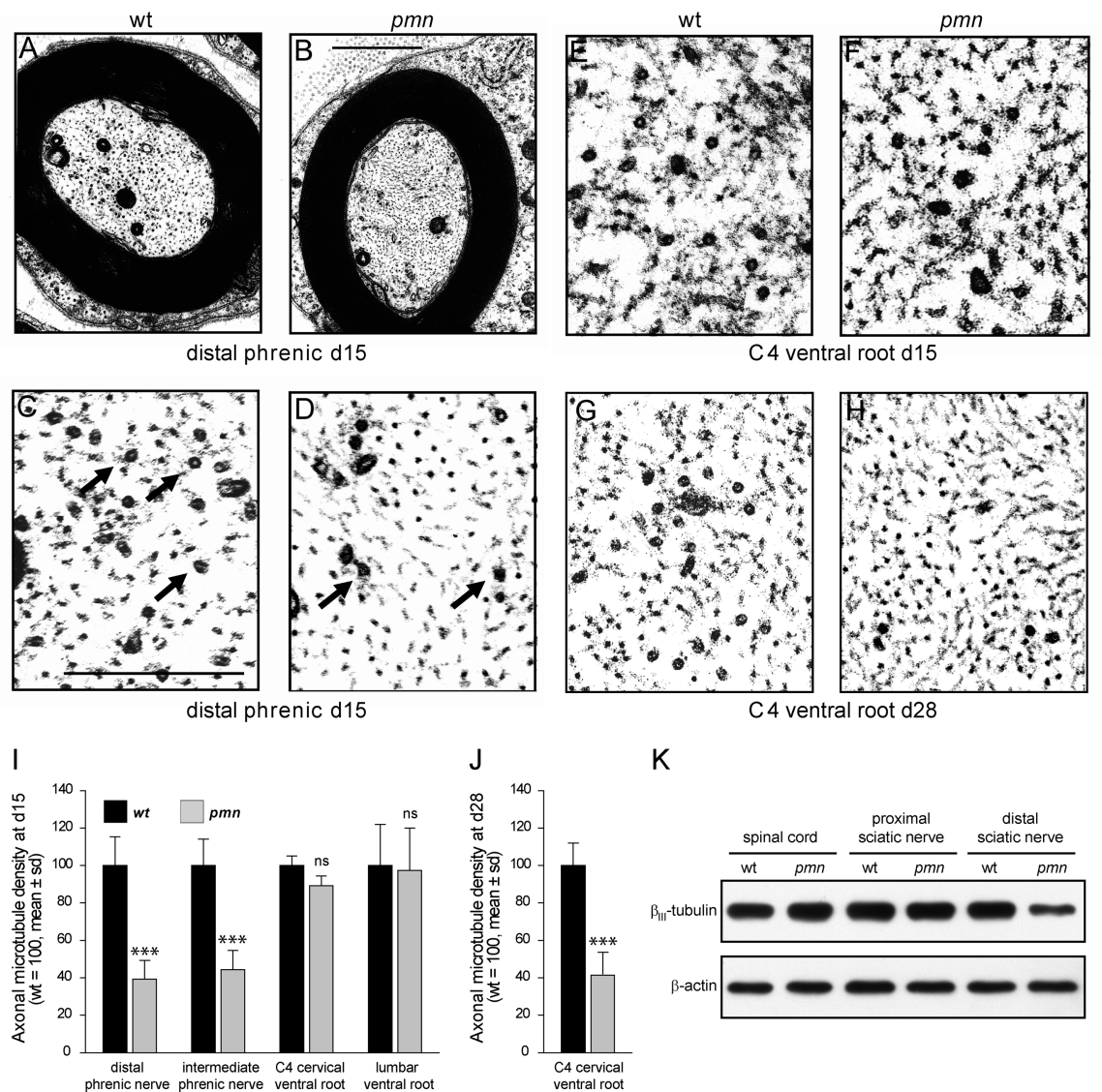

$\mathrm{K}$

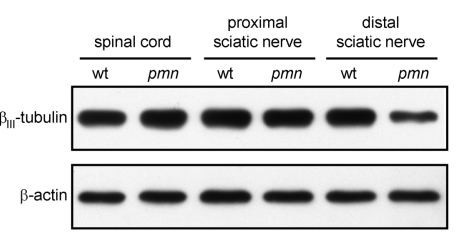

Figure 1. Axonal microtubules and tubulin levels in pmn mice. $\boldsymbol{A}, \boldsymbol{B}$, Electron micrographs showing entire cross sections through distal phrenic nerves from 15 -d-old early symptomatic pmn mice and wild-type (wt) littermate mice. C, D, High-power electron micrographs from distal phrenic nerve axons at day 15 . Microtubules (arrows) in pmn phrenic nerve axons are rarefied, whereas intermediate filaments are preserved. $\boldsymbol{E}, \boldsymbol{F}$, High-power electron micrographs from $(4$ ventral roots at day $15 . \mathbf{G}, \boldsymbol{H}$ High-power electron micrographs from C 4 ventral roots at day 28 . Scale bars: $A, B, 1 \mu \mathrm{m} ; \boldsymbol{C}-\boldsymbol{H}, 0.5 \mu \mathrm{m}$. I, Diagram showing that axonal microtubule densities in $p m n$ phrenic nerves mice are reduced by 61 and $56 \%$, respectively, at the distal and intermediate level compared with those in wild-type nerves ( ${ }^{* * *} p<0.0001$, Student's $t$ test). No significant microtubule loss is observed in cervical and lumbar ventral root motor axons of $15-\mathrm{d}-0 \mathrm{ld}$ pmn mice. A total of 378 individual axon cross sections were analyzed. $J$, Diagram showing reduction of microtubule densities in 44 ventral roots of $28-\mathrm{d}-0 \mathrm{ld} p m n$ mice ${ }^{* * *} p<0.0001$, Student's $t$ test). $\boldsymbol{K}$, Western blot analysis showing protein levels of $\beta_{\| 1}$-tubulin and $\beta$-actin in lysates from lumbar spinal cord and proximal and distal sciatic nerves at day 15 . Note the reduction of $\beta_{\| 1}$-tubulin in distal sciatic nerves of $p m n$ mice.

formaldehyde for $20 \mathrm{~min}$ at room temperature, blocked for $30 \mathrm{~min}$ in PBS containing $5 \%$ goat serum, $1 \%$ BSA, and $0.5 \%$ Triton X-100, and immunostained. NSC34 cells (Cashman et al., 1992) were cultured in DMEM supplemented with $10 \%$ fetal calf serum and transfected with DNA plasmids and lipofectamine (Invitrogen). To induce Golgi disassembly, cells were treated with $10 \mu \mathrm{m}$ brefeldin A for the indicated times, and reassembly was induced by washout for $30 \mathrm{~min}$ in culture medium.

For quantification of GFP- $\alpha$-tubulin and Discosoma red (DsRed) fluorescence, images were acquired in electroporated motor neurons cultured for 2 or $3 \mathrm{~d}$ in vitro (DIV) from wild-type and pmn embryos or transduced with siRNAs, respectively. Images from cell bodies or distal axons were obtained by confocal microscopy in optical sections of 2.8 $\mu \mathrm{m}$ using identical acquisition parameters in each experiment and analyzed by MetaMorph (Universal Imaging, Downingtown, PA). Ratios of GFP- $\alpha$-tubulin to DsRed were calculated from mean fluorescent intensities of each condition and experiment.

Microtubule growth assays were performed as described by Ahmad and Baas (1995) with the following modifications. Primary motor neurons were allowed to attach for $45 \mathrm{~min}$. Microtubules were depolymerized by adding $10 \mu \mathrm{M}$ nocodazole and incubated for $6 \mathrm{~h}$ at $37^{\circ} \mathrm{C}$. Nocodazole was washed out with warm culture medium, and neurons were further incubated for 0,1 , or $30 \mathrm{~min}$. Cultures were rinsed in PHEM (60 mM PIPES, 25 mm HEPES, $10 \mathrm{~mm}$ EGTA, $2 \mathrm{~mm} \mathrm{MgCl}_{2}$, and $1 \%$ formal- dehyde, $\mathrm{pH}$ 6.9) and extracted for $3 \mathrm{~min}$ in PHEM containing $0.2 \%$ Triton X-100, and 20 $\mu \mathrm{M}$ taxol, fixed, blocked, and immunostained for $\beta_{\mathrm{III}}$-tubulin and $\gamma$-tubulin to visualize microtubules and centrosomes, respectively. Images were obtained by confocal microscopy in sections of $2.5 \mu \mathrm{m}$ optical thickness covering the centrosome using identical acquisition parameters. Mean $\beta_{\mathrm{III}}$-tubulin fluorescence and the length of microtubules emanating from the centrosome were measured using MetaMorph and NIH ImageJ software, respectively.

Statistical analyses. Experiments were performed in duplicate or triplicate and repeated at least once. Data were analyzed with Excel (Microsoft, Seattle, WA); statistical testing and linear regression analysis were performed with SigmaStat 3.1 (Systat, Evanston, IL). When data showed a Gaussian distribution, they were analyzed with Student's $t$ test (two-tailed, unpaired); otherwise the Mann-Whitney $U$ test was used.

\section{Results}

Retrograde progression of axonal microtubule loss in pmn mice

Homozygous pmn mice develop first signs of muscle atrophy and paresis at 2 weeks of age and die by respiratory failure 4 to 5 weeks later (Schmalbruch et al., 1991). Motor neuron degeneration in affected mice starts at endplates and distal axons and progresses retrogradely (Schmalbruch et al., 1991). Proximal motor axons in ventral roots, however, show only modest degeneration (Schmalbruch et al., 1991), and spinal motor neuron cell bodies are preserved until end stage (Haase et al., 1997). To assess the role of microtubules in the axonal dying back process, we selected the phrenic nerve that contains mainly motor axons (Langford and Schmidt, 1983) and analyzed it at a distal level, close to the diaphragm, and at an intermediate level corresponding to the thoracic inlet. We also investigated C4 ventral root nerves because they contain the most proximal phrenic axons. As time points, we chose day 15 (disease onset) and day 28 (advanced disease stage). Using electron microscopy, we determined microtubule number and axonal surface in at least 10 entire cross-sectional axon profiles per nerve in four wild-type and four pmn littermate mice (Fig. $1 A, B$ ).

In normal phrenic nerves, we counted a mean of $15.2 \pm 2.3$ microtubules $/ \mu \mathrm{m}^{2}$ cross-sectional area of the distal axon (means of mean $\pm \mathrm{SD}$ ). In distal phrenic nerves of pmn mice, axonal microtubule densities were reduced to $6.0 \pm 1.6$ microtubules/ $\mu \mathrm{m}^{2}$, corresponding to $39 \pm 10 \%$ of normal ( $p<0.0001$ ) (Fig. $1 C, D, I)$. A similar reduction in axonal microtubule density ( $44 \pm 9 \%$ of normal; $p<0.0001$ ) was found at the intermediate level (Fig. 1I). Interestingly however, C4 ventral roots from pmn mice displayed no significant reduction in axonal microtubule density ( $89 \pm 5 \%$ of wild type) (Fig. $1 E, F, I)$. Lumbar ventral roots that supply the most severely affected territories in $p m n$ mice also showed normal axonal microtubule densities (97 \pm $22 \%$ of wild type) (Fig. 1I). These findings were further supported by Western blot analysis of neuronal $\beta_{\mathrm{III}}$-tubulin levels in 
distal and proximal sciatic nerves and lumbar spinal cord of 15-d-old mice. In pmn mice, the $\beta_{\mathrm{III}}$-tubulin levels were significantly reduced in distal sciatic nerves but normal in proximal nerves and spinal cord (Fig. $1 K$ ).

To analyze the temporal progression of microtubule loss in pmn mice, we studied C4 cervical ventral roots of 28 -d-old pmn mice (Fig. $1 G, H$ ). At this advanced disease stage, microtubule densities were reduced to $40 \pm 13 \%$ of normal (Fig. $1 \mathrm{~J}$ ). Axonal microtubule loss in pmn motor nerves thus first manifests distally and then progresses from distal to proximal, in parallel with the axonal dying back neuronopathy.

\section{Consequences of microtubule loss on axon degeneration}

We then investigated the requirement of microtubules for motor axon maintenance. To this purpose, we analyzed not only pmn and wild-type mice but also two lines of transgenic pmn mice complemented with wild-type TBCE (Martin et al., 2002), termed TBCE ${ }^{\mathrm{PA}} p m n$ and TB$\mathrm{CE}^{\mathrm{PC}}$ pmn. In $\mathrm{TBCE}^{\mathrm{PA}}$ pmn mice, disease onset is retarded by 2-3 weeks and survival is prolonged; in $\mathrm{TBCE}^{\mathrm{PC}} \mathrm{pmn}$ mice, disease is completely prevented. Using electron microscopy, we compared axonal pathology and microtubule density in distal phrenic nerves of $p m n$, wild-type and transgenic TBCE pmn mice (Fig. 2A-D). In phrenic nerves of 15-d-old pmn mice, we observed numerous axons with irregular contours (Fig. 2A) and a loss of $25 \%$ of myelinated axons $(195 \pm 25$, mean \pm SD) compared with wildtype littermate mice $(260 \pm 20$, mean \pm SD) (Fig. $2 C)$. In TB$\mathrm{CE}^{\mathrm{PA}}$ pmn mice, axon contour irregularities were present but less prominent than in pmn mice (Fig. $2 A$ ), and microtubule loss was observed in only one of four mice (Fig. $2 B, D$ ). In TBCE ${ }^{\mathrm{PC}} p m n$ mice, axon contour irregularities were completely absent, and axonal microtubule densities and numbers in phrenic nerves were normal (Fig. $2 A-C$ ). Linear regression analysis revealed a highly significant correlation between microtubule density and axon numbers $(r=0.939 ; \alpha=0.01 ; p<0.001)$ (Fig. $2 D)$. Microtubule densities below $10 / \mu \mathrm{m}^{2}$, corresponding to a microtubule loss of $\sim 40 \%$ were associated with beginning axon loss. Together, the clinical and EM data thus indicate a close correlation between axonal microtubule density, motor axon maintenance, and clinical disease course.

\section{TBCE accumulates at the Golgi apparatus of motor neurons} To investigate the role of TBCE in the maintenance of axonal microtubules, we studied its protein expression profile in the peripheral nervous system. In immunoblots of adult spinal cord extracts, our polyclonal antibody detected a single band of $59 \mathrm{kDa}$, corresponding to recombinant TBCE (Fig. 3A). On cervical spinal cord sections, TBCE was mainly expressed in ventral horn motor neurons and in neurons of superficial dorsal horn layers (Fig. 3B). To verify that TBCE is expressed in phrenic motor neurons in the cervical spinal cord, we used

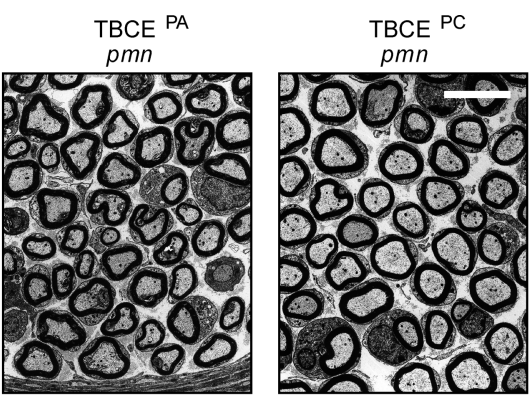

C
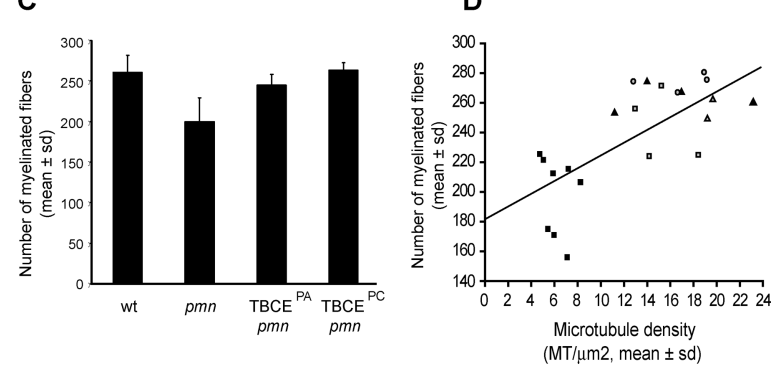

Figure 2. Requirements of microtubules for axon maintenance. $A$, Electron micrographs of distal phrenic nerves show irregushaped myelin sheaths and myelin debris as signs of axonal atrophy and degeneration in 15-d-old pmn mice compared with density below $10 / \mu \mathrm{m}^{2}$ ) was associated with beginning axon loss. Genotypes are as follows: $\mathbf{\square}, p m n ; \square$, wild type; $\mathbf{\Delta}, \operatorname{TBCE}^{\mathrm{PA}}$ $p m n ; \triangle$, TBCE ${ }^{\mathrm{PA}}$ wild type; $\mathrm{T}, \mathrm{TBCE} \mathrm{PC}^{\mathrm{PC}} \mathrm{pmn} ; \mathrm{O}, \mathrm{TBCE} \mathrm{PC}^{\mathrm{PC}}$ wild type. Scale bar, $10 \mu \mathrm{m}$.

retrograde rhodamine-dextran labeling. We found that all of them expressed high levels of TBCE in their soma (Fig. 3C). Surprisingly, however, TBCE was barely detectable in axons, identified by neurofilament labeling (Fig. 3D) or genetic labeling (Fig. 3E) in Thy1-YFP line 16 mice (Feng et al., 2000). In phrenic and sciatic nerves and also in cervical and lumbar ventral roots, TBCE expression predominated in Schwann cell bodies (Fig. 3 D, E and supplemental Fig. 1, available at www.jneurosci.org as supplemental material).

In motor neurons, TBCE accumulated at discrete tubulovesicular structures surrounding the nucleus that were reminiscent of the Golgi apparatus (Fig. 3F-I). Double immunolabeling and confocal microscopic analysis confirmed a striking overlap (Fig. $3 F, G$ ) between TBCE and the two cis-Golgi markers GM130 (Nakamura et al., 1995) and p115 (Sapperstein et al., 1995). The TBCE-positive structures were often found juxtaposed to Vtilastained trans-Golgi compartments (Fig. $3 \mathrm{H}$ ) but clearly distinct from Vtilb-stained post-Golgi compartments (Fig. 3I). TBCE accumulation at the Golgi was also observed in Schwann cells, as shown by TBCE and GM130 double immunolabeling (supplemental Fig. $1 D, E$, available at www.jneurosci.org as supplemental material). Golgi localization of TBCE was confirmed with a second antibody against TBCE and specificity by antibody preabsorption on TBCE peptides or on recombinant TBCE proteins (data not shown).

Previous TBCE overexpression studies in HeLa cells had detected TBCE only in the cytoplasm (Bhamidipati et al., 2000; Tian et al., 2006). To test this, we overexpressed GFP- and FLAGtagged TBCE in the NSC34 motor neuron cell line (Cashman et al., 1992). When expressed at a low level, tagged TBCE could be clearly detected at Golgi membranes (supplemental Fig. 2A, 
A
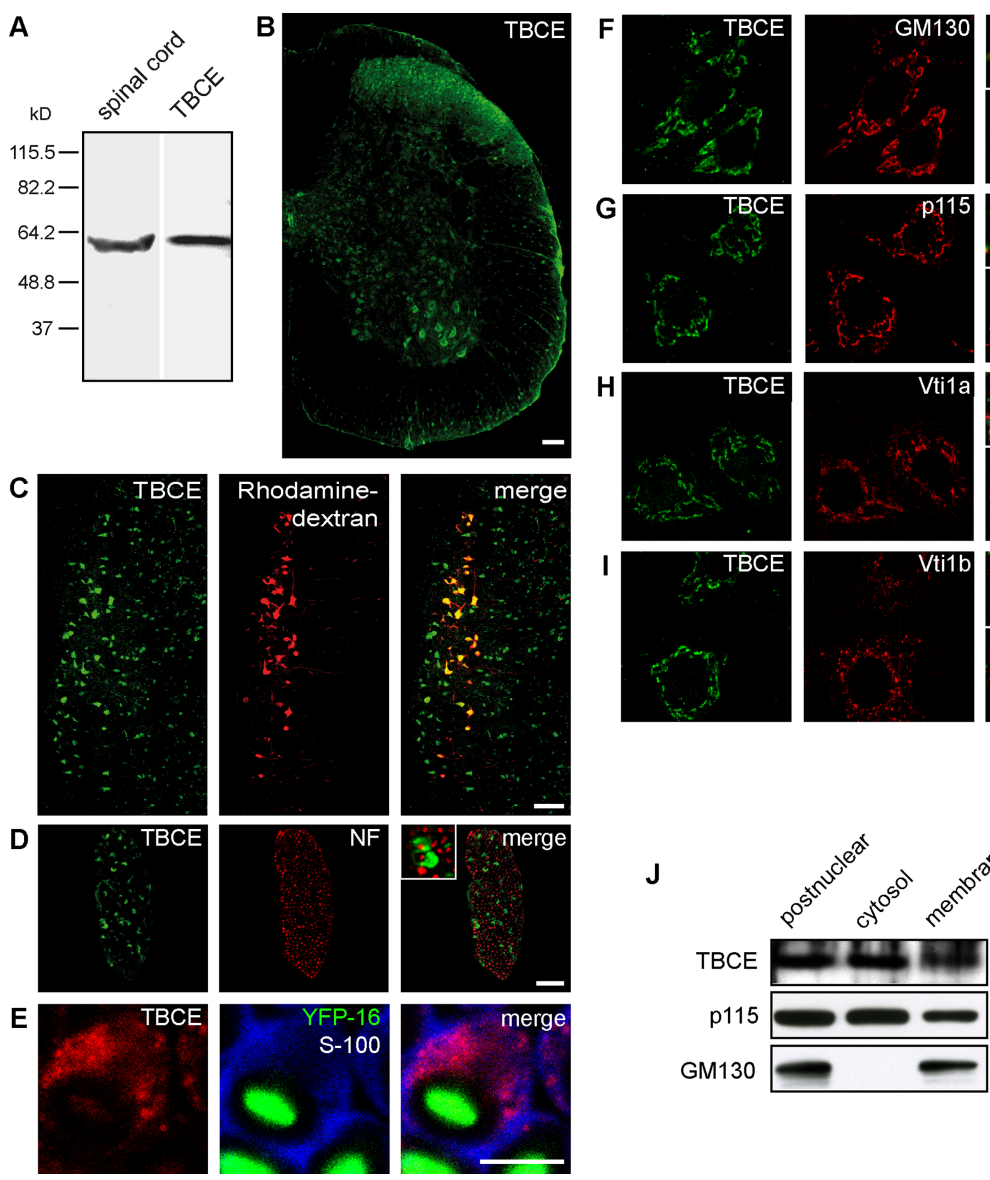

$\mathbf{J}$

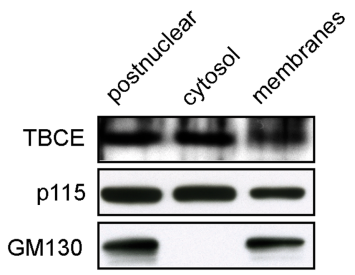

Figure 3. TBCE accumulation at the Golgi apparatus of spinal motor neurons. $\boldsymbol{A}$, Western blot analysis shows that a polyclonal antibody directed against murine TBCE detects a band of $\sim 59 \mathrm{kDa}$ in adult spinal cord protein extracts and in COS cells overexpressing TBCE. $\boldsymbol{B}$, Immunolabeling for TBCE in an adult cervical spinal cord cross section. $\boldsymbol{C}$, TBCE immunostaining in retrogradely labeled phrenic motor neurons on a frontal section of adult cervical spinal cord. $\boldsymbol{D}$, Immunolabeling for TBCE and neurofilament medium chain (NF) in a ventral root shows that TBCE is barely detectable in axons. $\boldsymbol{E}$, Triple labeling for TBCE (in red), S-100 (in blue), and the axon (in green) in the sciatic nerve of a Thy1-YFP line 16 mouse shows TBCE expression in the cell body of a Schwann cell. $\boldsymbol{F}, \mathbf{G}$, Immunolabeling for TBCE and the cis-Golgi markers GM130 (F) or p115 (G) demonstrates that TBCE decorates cis-Golgi membranes in motor neurons of adult spinal cord. $\boldsymbol{H}_{\iota} \boldsymbol{I}$, Immunolabeling for TBCE and Vti1a $(\boldsymbol{H})$, a trans-Golgi marker, or Vti1b $(\boldsymbol{I})$, a marker of post-Golgi compartments. Insets show magnified areas depicted by arrows. Scale bars: $\boldsymbol{B}-\boldsymbol{D}, 100 \mu \mathrm{m} ; \boldsymbol{E}, 5 \mu \mathrm{m} ; \boldsymbol{F}-\boldsymbol{I}$, $20 \mu \mathrm{m}$. J, Western blot analysis showing distribution of TBCE, p115, and GM130 in postnuclear, cytosolic, and crude membrane fractions of spinal cord.

available at www.jneurosci.org as supplemental material). After high-level expression, however, tagged TBCE was found exclusively in the cytoplasm. This discrepancy is probably due to the fact that high-level TBCE overexpression disrupts the cellular microtubule network that is required for maintenance of the Golgi apparatus (supplemental Fig. 2A-C, available at www. jneurosci.org as supplemental material).

Golgi proteins can be membrane bound, like the Golgi matrix protein GM130 (Nakamura et al., 1995), or peripheral membrane-associated, like the vesicle-tethering protein p115, which shuttles between membrane and cytosolic pools (Brandon et al., 2006). To distinguish between these possibilities for TBCE, we prepared subcellular fractions from spinal cord. TBCE was present in both crude membrane and cytosolic fractions, in a ratio similar to p115 (Fig. 3J). GM130 was found exclusively in the membrane fraction, as expected (Fig. 3J). Collectively, our immunohistochemical and biochemical data thus identify TBCE as the first tubulin-specific chaperone that accumulates at the Golgi apparatus.
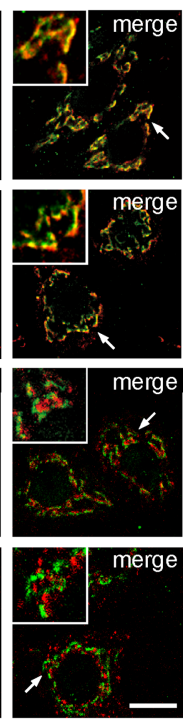

TBCE is destabilized at the Golgi apparatus in pmn mice and is restored by transgenic TBCE complementation To explore the molecular causes of microtubule loss in pmn mice, we analyzed whether the protein levels or subcellular localization of TBCE were modified in pmn motor neurons in vivo. Our previous in vitro studies had indicated that the pmn mutation alters the conformation and reduces the half-life of the TBCE protein (Martin et al., 2002). Western blot analyses now showed that TBCE protein levels in pmn spinal cords were drastically lower than in wild-type spinal cords at both disease onset (Fig. $4 A$ ) and end stage (Fig. $4 B$ ). Immunofluorescence analyses confirmed that TBCE expression at the Golgi apparatus was reduced in cervical and lumbar pmn motor neurons at postnatal day 15 (P15) (Fig. $4 C-E$ ) and P35 (data not shown). Similar observations were made in Schwann cells in the sciatic nerve (supplemental Fig. $1 B-E$, available at www.jneurosci. org as supplemental material). In conclusion, the pmn mutation destabilizes TBCE and reduces its steady-state levels at the Golgi apparatus in vivo.

To determine the levels of TBCE protein required for motor axon maintenance, we analyzed the two lines of transgenic TBCE $p m n$ mice. In these mice, wild-type TBCE is expressed under control of the neuron-specific NSE promoter (Forss-Petter et al., 1990). Western blot analyses showed that spinal cord levels of TBCE protein were intermediate in $\mathrm{TBCE}^{\mathrm{PA}}$ pmn mice and supranormal in $\mathrm{TBCE}^{\mathrm{PC}}$ pmn mice compared with $p m n$ and wild-type mice (Fig. $4 A, B)$. Immunostainings of cervical and lumbar spinal cord motor neurons showed that TBCE expression at the Golgi apparatus was partially restored in $\mathrm{TBCE}^{\mathrm{PA}} \mathrm{pmn}$ mice and normal in TBCE ${ }^{\text {PC }}$ pmn mice (Fig. $4 D, E$ ). Together, the biochemical, electron microscopic, and clinical data thus demonstrate that TBCE protein levels in spinal motor neurons determine the histopathological and phenotypic severity of progressive motor neuronopathy.

\section{Effects of TBCE depletion in motor neuron cultures}

Microtubules are made of $\alpha / \beta$-tubulin dimers that are generated in a complex biological process requiring the sequential action of prefoldin, CCT (cytosolic chaperonin complex), and five tubulin-specific chaperones. During this process, TBCE assists in the folding of $\alpha$-tubulin and the formation of $\alpha / \beta$-tubulin heterodimers (Tian et al., 1996, 1997). To investigate the function of TBCE in motor neurons, we performed RNA interferencemediated TBCE depletion experiments in NSC34 cells. Western blot analysis showed that endogenous TBCE was efficiently depleted by siRNAs (Fig. 5A). TBCE depletion had no effect on total levels of $\alpha$ - or $\beta_{\mathrm{III}}$-tubulin (Fig. 5A). TBCE-depleted cells, how- 
ever, contained more soluble and less precipitable, microtubule-incorporated, $\alpha$-tubulin than control cells (Fig. 5B,C), suggesting that some $\alpha$-tubulin was not correctly folded and polymerization incompetent.

In neurons, tubulins are mainly synthesized in the cell body (Eng et al., 1999), and most of them are rapidly routed into the axon (Campenot et al., 1996). Our in vivo observations in pmn mice showed that microtubule loss starts in the distal axon and progresses retrogradely. We therefore wondered whether TBCE is required for axonal tubulin routing. To address this question, we used embryonic motor neurons in primary culture. To monitor their axonal tubulin routing, we electroporated them with a GFP- $\alpha$-tubulin expression vector along with a DsRed vector and siRNAs. In si-luciferase-transduced control motor neurons, newly synthesized GFP- $\alpha$-tubulin and DsRed were evenly distributed in cell bodies and axons (Fig. 5D). In TBCE-depleted motor neurons, however, the amount of GFP- $\alpha$-tubulin was reduced in distal axons (Fig. 5D). We therefore compared the fluorescence ratios of GFP- $\alpha$-tubulin with DsRed in motor neuron cell bodies and axons by confocal microscopy and quantitative image analysis (Fig. 5D-G). In cell bodies of TBCE-depleted cells, the mean GFP- $\alpha$ tubulin $/ \beta_{\mathrm{II}}$-tubulin fluorescence ratio was reduced to $74.3 \pm 1.7 \%$ of the ratio in control cells (mean $\pm \mathrm{SD} ; p<0.01$ ) (Fig. $5 G)$. In distal axons of TBCE-depleted cells, this ratio was reduced to $41.9 \pm 1.6 \%$ of the control value (mean $\pm \mathrm{SD} ; p<0.01$ ) (Fig. $5 G$ ), which is significantly lower than the reduction in the cell bodies. These results indicate that TBCE in motor neurons is not only required for proper tubulin folding but also for its axonal routing.

\section{Microtubule polymerization and axonal routing in pmn motor neurons}

To test the consequences of the pmn mutation on microtubule polymerization, we examined pmn and wild-type motor neurons in culture. Motor neurons were purified from individual embryos, seeded, and incubated for $6 \mathrm{~h}$ with $10 \mu \mathrm{M}$ nocodazole to depolymerize microtubules (Ahmad and Baas, 1995). In wildtype motor neurons, microtubules began to emanate from the centrosome as early as $1 \mathrm{~min}$ after nocodazole washout and formed extended microtubule asters at $30 \mathrm{~min}$ (Fig. 6A). In pmn motor neurons, microtubule polymerization was initially normal but severely affected at $30 \mathrm{~min}$ (Fig. $6 \mathrm{~B}$ ). At this time, the immunoreactivity of microtubule-incorporated $\beta_{\mathrm{III}}$-tubulin was reduced to $43.9 \pm 8.1 \%$ of wild type (mean \pm SD; $p<0.0001$ ) (Fig. $6 C)$, and microtubules were significantly shorter than in wildtype motor neurons (Fig. 6D). These results indicate that the pmn mutation in TBCE impairs microtubule polymerization.

We next analyzed axonal tubulin routing in pmn motor neurons. Motor neurons were electroporated with GFP- $\alpha$-tubulin and DsRed plasmids and cultured for 2 DIV. In cell bodies, the mean GFP- $\alpha$-tubulin $/ \beta_{\text {III }}$-tubulin fluorescence ratios were not significantly different between $p m n$ and wild-type motor neurons (Fig. $6 F$ ). In distal axons of pmn motor neurons, however, the mean GFP- $\alpha$-tubulin/DsRed ratio was reduced to $54.2 \pm 9.6 \%$ of wild type $(p<0.05)$ (Fig. $6 E, F)$. The reduction of tubulin levels in distal axons of $p m n$ motor neurons indicates that the pmn mutation in TBCE compromises axonal tubulin routing.

\section{The Golgi apparatus controls axonal tubulin routing in motor neurons}

To test whether the Golgi apparatus is involved in axonal tubulin routing, we pharmacologically disrupted this organelle with BFA. BFA inhibits activation of ADP-ribosylation factors (Donaldson et al., 1992), which causes Golgi disassembly and redistribution of its components into the endoplasmic reticulum (LippincottSchwartz et al., 1990), the cytosol (Klausner et al., 1992), or into so-called Golgi remnants (Seemann et al., 2000). In mock-treated NSC34 motor neurons (Fig. 7A), we found TBCE to be associated with GM130-stained cis-Golgi membranes, as in vivo. In BFAtreated motor neurons, GM130 localized to dispersed Golgi remnants, as expected, but TBCE was redistributed into the cytosol (Fig. 7A). The BFA-induced cytosolic TBCE redistribution was reversible on BFA washout (Fig. 7A) and not accompanied by a modification in cellular TBCE levels (Fig. 7B). Immunoblot analyses further confirmed that BFA had no significant effect on the 


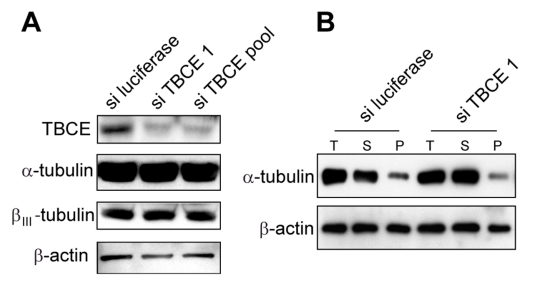

D

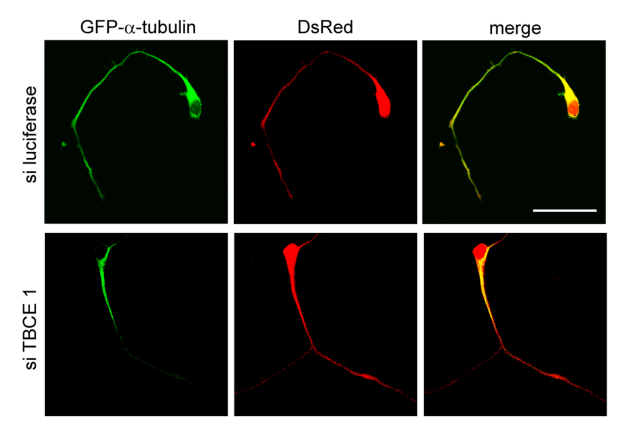

C

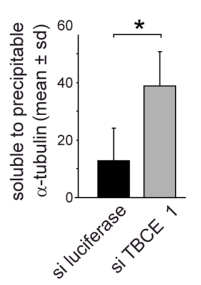

E
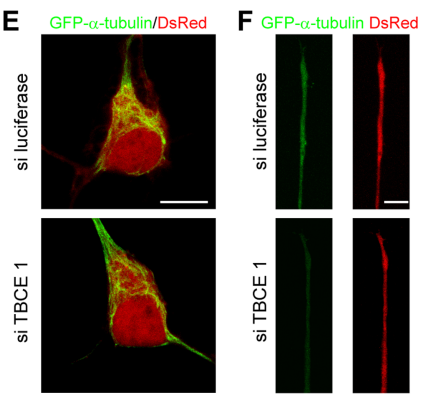

G

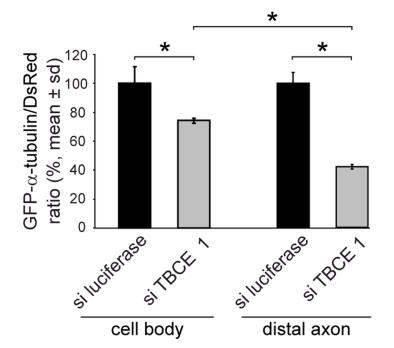

Figure 5. Role of TBCE in tubulin formation and axonal routing. $\boldsymbol{A}$, TBCE depletion in NSC34 cells. Western blots showing total levels of TBCE, $\alpha$-and $\beta_{\mathrm{III}}$-tubulin, and $\beta$-actin in cells 3 d after transfection of si-luciferase, si-TBCE 1 , or si-TBCE pool. $\boldsymbol{B}$, Western blot showing increased amounts of soluble $\alpha$-tubulin $(\mathrm{S})$ and reduced amounts of precipitable $\alpha$-tubulin (P) in subcellular fractions of TBCE-depleted NSC34 cells compared with control cells. T, Total tubulin in postnuclear supernatant. C, Diagram showing the increased ratio of soluble to precipitable $\alpha$-tubulin in TBCE-depleted NSC34 cells. Values were determined from blots of five independent experiments. siTBCE, $39 \pm 12$; si-luciferase, $13 \pm 11$ (means \pm SD). ${ }^{*} p<0.005$, Student's $t$ test. $\boldsymbol{D}-\boldsymbol{F}$, Images of primary motor neurons at 3 DIV after electroporation with GFP- $\alpha$-tubulin and DsRed expression vectors and siRNAs. Shown are low-power magnifications of neurons $(\boldsymbol{D})$ and high-power magnifications of cell bodies $(\boldsymbol{E})$ and distal axons $(\boldsymbol{F})$. Note diminished GFP- $\alpha$-tubulin fluorescence in the distal axons of TBCE-depleted motor neurons. $G$, Diagram showing the ratio of GFP- $\alpha$-tubulin to DsRed fluorescence in cell bodies and distal axons of electroporated motor neurons. After TBCE depletion, this ratio is significantly lower in distal axons than in cell bodies. Scale bars: $\boldsymbol{D}, 50 \mu \mathrm{m} ; \boldsymbol{E}, \boldsymbol{F}, 10 \mu \mathrm{m}$. Statistical significance: ${ }^{*} p<0.01$ Student's $t$ test. Data represent means of means \pm SD from three independent experiments ( $n=75$ neurons per condition).

total cellular amounts of GM130, $\alpha$-tubulin, or $\beta$-tubulin (Fig. $7 B)$ under these experimental conditions.

To test the effects of Golgi disruption on axonal tubulin routing, we electroporated motor neurons with GFP- $\alpha$-tubulin or GFP plasmids, treated them with BFA or mock (Fig. $7 C$ ), and counterstained them for $\beta_{\mathrm{III}}$-tubulin. BFA had no obvious effect on the levels or intracellular distribution of GFP (data not shown) or endogenous $\beta_{\mathrm{III}}$-tubulin (Fig. 7C). BFA, however, modified the intracellular distribution of GFP- $\alpha$-tubulin. In BFA-treated motor neurons, GFP- $\alpha$-tubulin was predominantly found in cell bodies and strikingly diminished in axons (Fig. 7C,D). Quantitative confocal analyses in distal axons of BFA-treated motor neurons confirmed that the ratio of GFP- $\alpha$-tubulin fluorescence to $\beta_{\mathrm{III}}$-tubulin fluorescence was reduced to $33.3 \pm 4.8 \%$ (mean \pm $\mathrm{SD})$ of the ratio in mock-treated motoneurons $(p<0.05$ as analyzed per Student's $t$ test; $n=30$ cells per condition). BFAinduced Golgi disruption and TBCE depletion, albeit differing in their molecular mode of action, thus have very similar effects on axonal tubulin routing. These data indicate that axonal tubulin routing in motor neurons is controlled at the Golgi apparatus and implicate TBCE in this process.

\section{Discussion}

\section{Subcellular origin of axonal degeneration}

Axonal degeneration, whether of traumatic, toxic, or genetic origin, often manifests as axonal dying back: distal axons are affected first, and degeneration apparently progresses from distal to proximal (Cavanagh, 1964; Coleman, 2005). The subcellular origin of such dying back processes remains debated (Conforti et al., 2007). "Centroneuronal" hypotheses have attributed the ax- onal dying back to dysfunction of the neuronal perikaryon and progressive withdrawal of metabolic support to the axon (Cavanagh, 1964) or to defects in the proximal axonal cytoskeleton and blockade of anterograde axonal transport (Griffin and Watson, 1988). "Axonal” hypotheses postulated that the degenerative process is triggered in the axon itself: Vincristine, a chemotherapeutic agent used in human cancer therapy, causes a peripheral neuropathy with prominent distal axonal degeneration (Bradley et al., 1970). The axonal dying back process can be mimicked in neuronal cultures (Ravula et al., 2007) in which topic application of Vincristine at clinically relevant concentrations injures the axon but not the neuronal soma (Silva et al., 2006). Several genetic studies have also linked impaired retrograde axonal transport to motor neuron degeneration. Mutation or disruption of the motor protein complex dynein/dynactin for example cause progressive motor neuron degeneration in mice (LaMonte et al., 2002; Hafezparast et al., 2003) and humans (Puls et al., 2003).

\section{Retrograde microtubule loss in pmn mice}

We here investigated how a missense mutation in TBCE causes axonal dying back in $p m n$ mice. We show that in normal mice, TBCE is expressed in motor neuron cell bodies in which it accumulates at the cis-Golgi apparatus. In early symptomatic pmn mice, TBCE is destabilized and lost from this organelle. Microtubules are first lost in distal motor axons and only at end stage in proximal motor axons. This retrograde microtubule loss parallels the axonal dying back: at disease onset, the extent of microtubule loss in distal phrenic nerves correlates with the severity of axonal degeneration and the axonal loss. At end stage of disease, microtubules (this study) and axonal diameters (Schmalbruch et al., 1991) are also reduced in ventral roots. We further show that neuron-specific TBCE complementation restores TBCE levels in spinal motor neurons of pmn mice and inhibits microtubule loss, axonal degeneration, and clinical disease in a dose-dependent manner. These data indicate that destabilization of TBCE in motor neurons is responsible for the axonal dying back process in pmn mice.

\section{How can a defective tubulin chaperone cause axonal dying back?}

Using cultured pmn motor neurons, we show that the pmn mutation compromises the routing of newly synthesized tubulin from the cell body to the distal axon and impedes the incorporation of tubulin into growing microtubules. In vivo analyses of early symptomatic pmn mice further demonstrate that neuronal $\beta_{\mathrm{III}}$-tubulin levels are reduced in distal sciatic nerves but normal in proximal nerves and corresponding lumbar spinal cord segments. Hoffman et al. (1992) reported that tubulins are anterogradely transported and continuously deposited into stationary axonal microtubules, which are stabilized when axons mature (Watson et al., 1990). Zenker and Hohberg (1973) emphasized 
that the proximal motor axon has a much smaller cross-sectional area and contains many fewer microtubules than all of its distal branches taken together. They found that the combined cross sections through all terminal axons of a typical A- $\alpha$-motor neuron contain 11 times as many microtubule profiles as the stem axon. These data suggest that defective axonal tubulin routing leads to reduced tubulin supply to distal axons and thereby causes microtubule rarefaction. Motor neurons might be particularly vulnerable to defective tubulin routing because of their extremely long axons and their extended axonal arborizations.

What is the role of the Golgi apparatus in axonal tubulin routing?

Studies in cultured neurons have shown that axonal tubulins are mainly synthesized in the cell soma (Eng et al., 1999) and transported into the distal axon within $2 \mathrm{~d}$ after synthesis (Campenot et al., 1996). Metabolic labeling experiments in compartmentalized cultures had provided evidence that this process depends on the Golgi apparatus (Campenot et al., 2003). Using immunohistochemical and biochemical experiments, we clearly identify TBCE as a peripheral membraneassociated protein of cis-Golgi membranes in vivo. In vitro data in cultured NSC 34 and primary motor neurons further confirm the accumulation of tagged and endogenous TBCE at this organelle. Functional TBCE depletion assays indicate that TBCE is required for axonal routing of tubulins, and BFA-mediated Golgi disruption experiments indicate that this process depends on an intact Golgi apparatus. TBCE is thus related to a growing number of Golgi proteins that control microtubule formation or dynamics, such as GMAP210 (Golgi microtubule-associated protein of $210 \mathrm{kDa}$ ) (Infante et al., 1999; Rios et al., 2004), AKAP350 (A kinase anchor protein 350) (Larocca et al., 2006), and CLASPs $1 / 2$ (cytoplasmic linker associated proteins 1/2) (Mimori-Kiyosue et al., 2005).

\section{Are defects in tubulin chaperones also implicated in other forms of axonal degeneration?}

Human TBCE deletions have been found in children with HRD (hypoparathyroidism, growth retardation, dysmorphism) syndrome (Parvari et al., 2002) that eventually develop motor neuron disease symptoms when becoming elder (Parvari et al., 2007). The TBCE-related tubulin chaperone TBCB has been reported to be
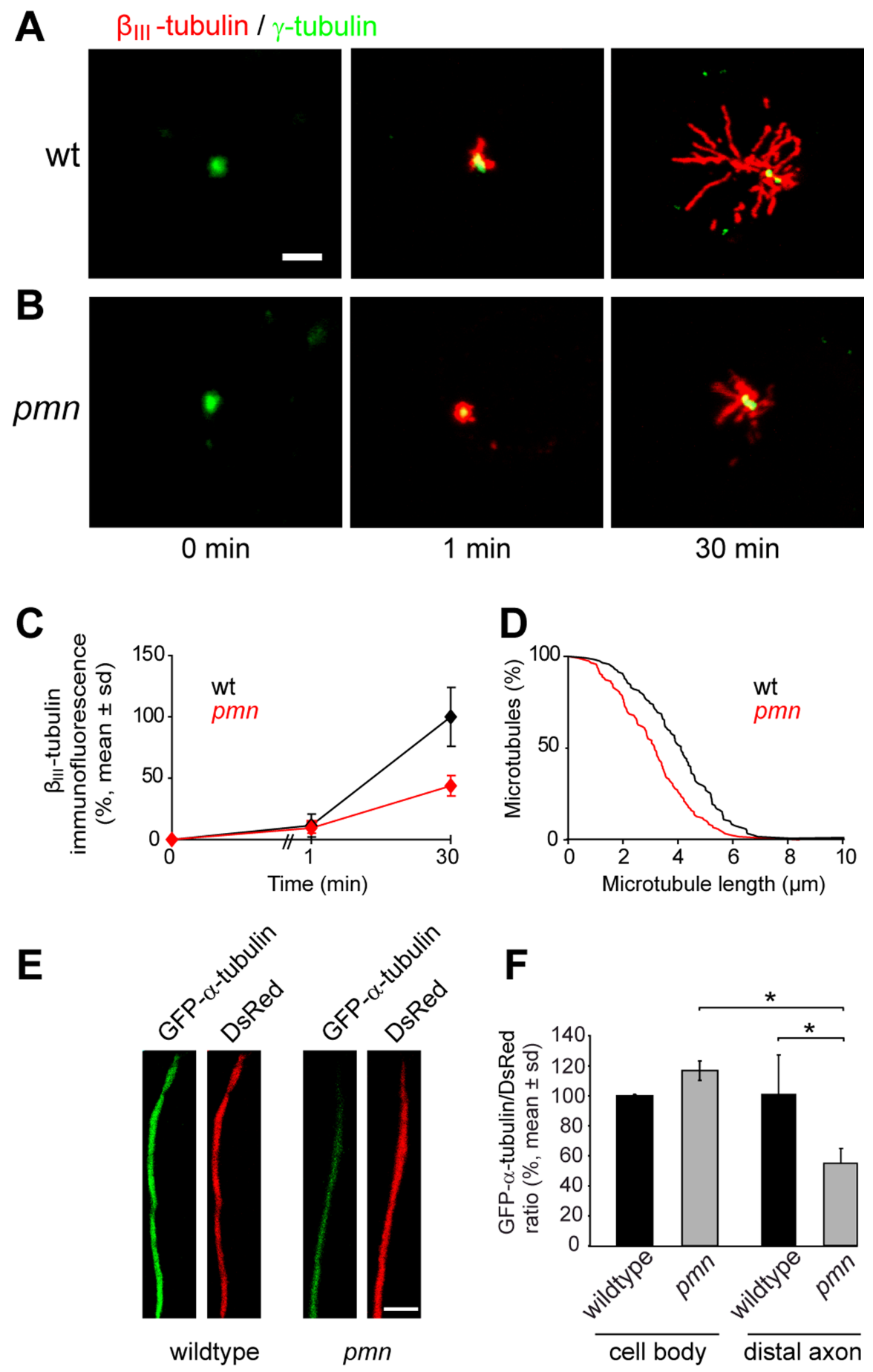

Figure 6. Microtubule polymerization and axonal tubulin routing in cultured pmn motor neurons. $\boldsymbol{A}, \boldsymbol{B}$, Images showing microtubule regrowth in wild-type (wt) and pmn motor neurons at 0,1 , and 30 min after nocodazole washout. Microtubules are labeled for $\beta_{\mathrm{III}}$-tubulin and centrosomes for $\gamma$-tubulin. Note complete microtubule depolymerization at the 0 min time point. $\boldsymbol{C}$, Time course of microtubule regrowth after nocodazole washout. At $30 \mathrm{~min}$, pmn motor neurons display a significant reduction in $\beta_{\mathrm{III}}$-tubulin immunofluorescence levels compared with wild-type motor neurons ( $p<0.0001$, Mann-Whitney $U$ test, arbitrary units). Each data point represents 120 cells from three independent experiments. D, Microtubule length distribution 30 min after nocodazole washout.pmn, $3.2 \pm 1.5 \mu \mathrm{m}$; wild type, $4.1 \pm 1.6 \mu \mathrm{m}$ (means $\pm \mathrm{SD})(p<0.0001$, Mann-Whitney $U$ test; $n=120$ per genotype). $\boldsymbol{E}$, Images of distal axons from wild-type and pmn primary motor neurons electroporated with GFP- $\alpha$-tubulin and DsRed expression vectors and analyzed at 2 DIV by quantitative image analysis. $F$, Diagram showing the ratio of GFP- $\alpha$-tubulin to DsRed fluorescence in cell bodies and distal axons of wild-type and pmn motor neurons. In distal axons, this ratio is significantly lower in pmn than in wild-type motor neurons $\left({ }^{*} p<0.05, t\right.$ test). Data represent means $\pm S D$ from two independent experiments (60 cells per genotype). Scale bars: $\boldsymbol{A}, 2 \mu \mathrm{m} ; \boldsymbol{E}, 10 \mu \mathrm{m}$. 

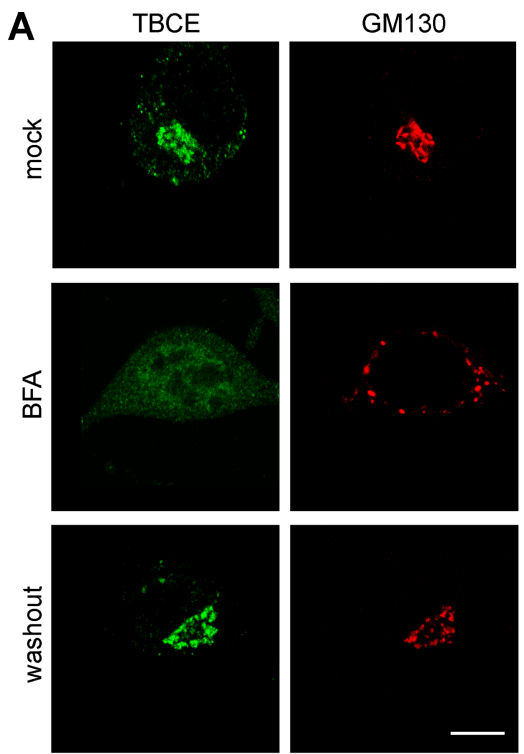

B

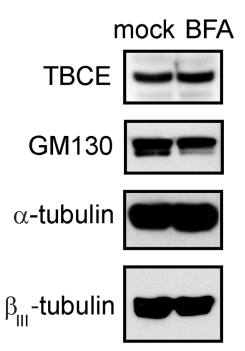

C
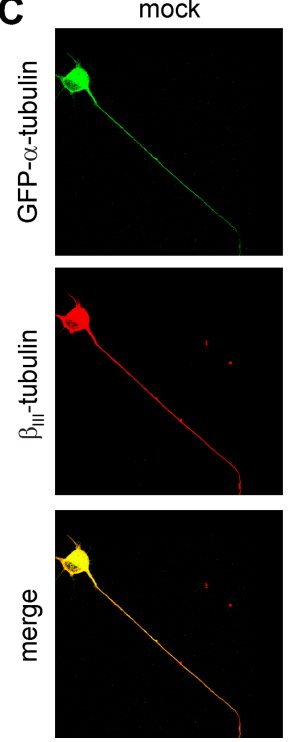

BFA
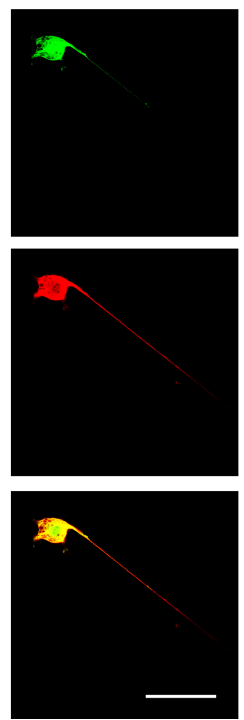

D
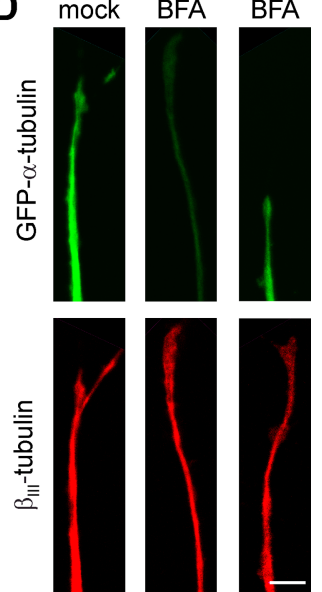

Figure 7. Effects of BFA-mediated Golgi disassembly on axonal tubulin routing in cultured motor neurons. A, Images of TBCE/GM130-immunostained NSC34 cells after mock treatment, BFA treatment ( $5 \mathrm{~h}$ ), or BFA treatment and subsequent washout (30 min). BFA induces dispersal of GM130-stained Golgi elements and complete TBCE redistribution into the cytoplasm; the BFA effects are reversible. $B$, Western blot analysis of NSC34 cell lysates showing that BFA treatment does not affect the overall levels of TBCE, $\alpha$-tubulin, $\beta_{\| 1 \mid}$ tubulin, or GM130. $C$, Images of primary motor neurons electroporated with the GFP- $\alpha$-tubulin vector at 2 DIV, after treatment with BFA (20 h) or mock, and counterstained for endogenous $\beta_{\| 1 I}$-tubulin. Note diminished GFP- $\alpha$-tubulin fluorescence in axons of BFA-treated motor neurons. D, High-magnification images showing distal axon segments of electroporated primary motor neurons treated with BFA or mock and

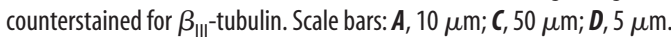

dysregulated in gigaxonin knock-out mice, a model of human giant axonal neuropathy (Wang et al., 2005). Gigaxonin binds $\mathrm{TBCB}$, promotes its poly-ubiquitination and thereby targets it to the proteasome for degradation. The absence of gigaxonin leads to an accumulation of TBCB and a loss of microtubules in neurons (Wang et al., 2005). Interestingly, gigaxonin, like TBCE, localizes at the Golgi apparatus (Cullen et al., 2004). Wobbler mice, a model of progressive motor neuron degeneration, are mutated in VPS54 (vacuolar protein sorting 54), a protein of the Golgi-associated retrograde complex (Schmitt-John et al., 2005). In these mice, defective axonal transport (Mitsumoto and Gambetti, 1986) and progressive axonal degeneration (Mitsumoto and Bradley, 1982) are associated with downregulation of the tubulin chaperone TBCA and of $\alpha 3$-tubulin (Perrin et al., 2006). The role of tubulin chaperones and their interactors at the Golgi apparatus thus warrants additional investigations.

\section{Therapeutic implications}

In the past, $p m n$ mice have been instrumental in developing new axonoprotective strategies. Crossing of $p m n$ mice with Wld ${ }^{\mathrm{s}}$ mice reduced axonal degeneration and extended the lifespan of pmn mice (Ferri et al., 2003). The mechanisms remained enigmatic because $\mathrm{Wld}^{\mathrm{S}}$ is a nuclear protein and undetectable in axons. Recently, Simonin et al. (2007) reported an upregulation of kinesin-1 in $p m n \times$ Wld $^{\mathrm{S}}$ motor neurons. Together, these data, the known role of kinesins in axonal tubulin transport (Terada et al., 2000; Kimura et al., 2005), and our findings raise the possibility that Wld ${ }^{\mathrm{S}}$ protects $p m n$ motor neurons by recovering their deficit in axonal tubulin supply. Various studies have also shown that gene therapy with neurotrophic factors can provide substantial therapeutic benefit to pmn mice (Sendtner et al., 1992; Sagot et al., 1995a; Haase et al., 1997; Bordet et al., 1999). It has been shown that neurotrophic factors can be internalized into signaling endosomes and retrogradely transported toward the Golgi apparatus (Howe and Mobley, 2005). This suggests that neuro- trophic factors exert some of their therapeutic effects by modulating Golgi function and axonal tubulin routing.

\section{References}

Ahmad FJ, Baas PW (1995) Microtubules released from the neuronal centrosome are transported into the axon. J Cell Sci 108:2761-2769.

Bhamidipati A, Lewis SA, Cowan NJ (2000) ADP ribosylation factor-like protein 2 (Arl2) regulates the interaction of tubulin-folding cofactor D with native tubulin. J Cell Biol 149:1087-1096.

Boillee S, Vande Velde C, Cleveland DW (2006) ALS: a disease of motor neurons and their nonneuronal neighbors. Neuron 52:39-59.

Bömmel H, Xie G, Rossoll W, Wiese S, Jablonka S, Boehm T, Sendtner M (2002) Missense mutation in the tubulin-specific chaperone E (Tbce) gene in the mouse mutant progressive motor neuronopathy, a model of human motoneuron disease. J Cell Biol 159:563-569.

Bordet T, Schmalbruch H, Pettmann B, Hagège A, Castelnau-Ptakhine L, Kahn A, Haase G (1999) Adenoviral cardiotrophin-1 gene transfer protects pmn mice from progressive motor neuronopathy. J Clin Invest 104:1077-1085.

Bradley WG, Lassman LP, Pearce GW, Walton JN (1970) The neuromyopathy of vincristine in man. Clinical, electrophysiological and pathological studies. J Neurol Sci 10:107-131.

Brandon E, Szul T, Alvarez C, Grabski R, Benjamin R, Kawai R, Sztul E (2006) On and off membrane dynamics of the endoplasmic reticulumgolgi tethering factor p115 in vivo. Mol Biol Cell 17:2996-3008.

Brunialti ALB, Poirier C, Schmalbruch H, Guenet JL (1995) The mouse mutation progressive motor neuronopathy $(\mathrm{pmn})$ maps to chromosome 13. Genomics 29:131-135.

Campenot B, Lund K, Senger DL (1996) Delivery of newly synthesized tubulin to rapidly growing distal axons of sympathetic neurons in compartmented cultures. J Cell Biol 135:701-709.

Campenot RB, Soin J, Blacker M, Lund K, Eng H, MacInnis BL (2003) Block of slow axonal transport and axonal growth by brefeldin A in compartmented cultures of rat sympathetic neurons. Neuropharmacology 44:1107-1117.

Cashman NR, Durham HD, Blusztajn JK, Oda K, Tabira T, Shaw IT, Dahrouge S, Antel JP (1992) Neuroblastoma x spinal cord (NSC) hybrid cell lines resemble developing motor neurons. Dev Dyn 194:209-221.

Cavanagh JB (1964) The significance of the "dying back" process in experimental and human neurological disease. Int Rev Exp Pathol 3:219-267. 
Cifuentes-Diaz C, Nicole S, Velasco ME, Borra-Cebrian C, Panozzo C, Frugier T, Millet G, Roblot N, Joshi V, Melki J (2002) Neurofilament accumulation at the motor endplate and lack of axonal sprouting in a spinal muscular atrophy mouse model. Hum Mol Genet 11:1439-1447.

Coleman M (2005) Axon degeneration mechanisms: commonality amid diversity. Nat Rev Neurosci 6:889-898.

Conforti L, Adalbert R, Coleman MP (2007) Neuronal death: where does the end begin? Trends Neurosci 30:159-166.

Cullen VC, Brownlees J, Banner S, Anderton BH, Leigh PN, Shaw CE, Miller CC (2004) Gigaxonin is associated with the Golgi and dimerises via its BTB domain. NeuroReport 15:873-876.

Devon RS, Orban PC, Gerrow K, Barbieri MA, Schwab C, Cao LP, Helm JR, Bissada N, Cruz-Aquado R, Davidson TL, Witmer J, Metzler M, Lam CK, Tetzlaff W, Simpson EM, McCaffery JM, El-Husseini AE, Leavitt BR, Hayden MR (2006) Als2-deficient mice exhibit disturbances in endosome trafficking associated with motor behavioral abnormalities. Proc Natl Acad Sci USA 103:9595-9600.

Donaldson JG, Finazzi D, Klausner RD (1992) Brefeldin A inhibits Golgi membrane-catalysed exchange of guanine nucleotide onto ARF protein. Nature 360:350-352.

Eng H, Lund K, Campenot RB (1999) Synthesis of $\beta$-tubulin, actin, and other proteins in axons of sympathetic neurons in compartmented cultures. J Neurosci 19:1-9.

Feng G, Mellor RH, Bernstein M, Keller-Peck C, Nguyen QT, Wallace M, Nerbonne JM, Lichtman JW, Sanes JR (2000) Imaging neuronal subsets in transgenic mice expressing multiple spectral variants of GFP. Neuron 28:41-51.

Ferri A, Sanes JR, Coleman MP, Cunningham JM, Kato AC (2003) Inhibiting axon degeneration and synapse loss attenuates apoptosis and disease progression in a mouse model of motoneuron disease. Curr Biol 13:669-673.

Fischer LR, Culver DG, Tennant P, Davis AA, Wang M, Castellano-Sanchez A, Khan J, Polak MA, Glass JD (2004) Amyotrophic lateral sclerosis is a distal axonopathy: evidence in mice and man. Exp Neurol 185:232-240.

Forss-Petter S, Danielson PE, Catsicas S, Battenberg E, Price J, Nerenberg M, Sutcliffe JG (1990) Transgenic mice expressing beta-galactosidase in mature neurons under neuron-specific enolase promoter control. Neuron 5:187-197.

Frey D, Schneider C, Xu L, Borg J, Spooren W, Caroni P (2000) Early and selective loss of neuromuscular synapse subtypes with low sprouting competence in motoneuron diseases. J Neurosci 20:2534-2542.

Griffin JW, Watson DF (1988) Axonal transport in neurological disease. Ann Neurol 23:3-13.

Haase G, Kennel P, Pettmann B, Vigne E, Akli S, Revah F, Schmalbruch H, Kahn A (1997) Gene therapy of a murine motor neuron disease using adenoviral vectors for neurotrophic factors. Nat Med 3:429-436.

Hafezparast M, Klocke R, Ruhrberg C, Marquardt A, Ahmad-Annuar A, Bowen S, Lalli G, Witherden AS, Hummerich H, Nicholson S, Morgan PJ, Oozageer R, Priestley JV, Averill S, King VR, Ball S, Peters J, Toda T, Yamamoto A, Hiraoka Y, et al. (2003) Mutations in dynein link motor neuron degeneration to defects in retrograde transport. Science 300:808-812.

Hoffman PN, Lopata MA, Watson DF, Luduena RF (1992) Axonal transport of class II and III beta-tubulin: evidence that the slow component wave represents the movement of only a small fraction of the tubulin in mature motor axons. J Cell Biol 119:595-604.

Howe CL, Mobley WC (2005) Long-distance retrograde neurotrophic signaling. Curr Opin Neurobiol 15:40-48.

Infante C, Ramos-Morales F, Fedriani C, Bornens M, Rios RM (1999) GMAP-210, a cis-Golgi network-associated protein, is a minus end microtubule-binding protein. J Cell Biol 145:83-98.

Jacquier A, Buhler E, Schafer MK, Bohl D, Blanchard S, Beclin C, Haase G (2006) Alsin/Racl signaling controls survival and growth of spinal motoneurons. Ann Neurol 60:105-117.

Kennel PF, Finiels F, Revah F, Mallet J (1996a) Neuromuscular function impairment is not caused by motor neurone loss in FALS mice: an electromyographic study. NeuroReport 7:1427-1431.

Kennel PF, Fonteneau P, Martin E, Schmidt JM, Azzouz M, Borg J, Guenet JL, Schmalbruch H, Warter JM, Poindron P (1996b) Electromyographical and motor performance studies in the pmn mouse model of neurodegenerative disease. Neurobiol Disease 3:137-147.

Kimura T, Watanabe H, Iwamatsu A, Kaibuchi K (2005) Tubulin and
CRMP-2 complex is transported via Kinesin-1. J Neurochem 93:1371-1382.

Klausner RD, Donaldson JG, Lippincott-Schwartz J (1992) Brefeldin A: insights into the control of membrane traffic and organelle structure. J Cell Biol 116:1071-1080.

LaMonte BH, Wallace KE, Holloway BA, Shelly SS, Ascano J, Tokito M, Van Winkle T, Howland DS, Holzbaur EL (2002) Disruption of dynein/dynactin inhibits axonal transport in motor neurons causing late-onset progressive degeneration. Neuron 34:715-727.

Langford LA, Schmidt RF (1983) An electron microscopic analysis of the left phrenic nerve in the rat. Anat Rec 205:207-213.

Larocca MC, Jin M, Goldenring JR (2006) AKAP350 modulates microtubule dynamics. Eur J Cell Biol 85:611-619.

Lippincott-Schwartz J, Donaldson JG, Schweizer A, Berger EG, Hauri HP, Yuan LC, Klausner RD (1990) Microtubule-dependent retrograde transport of proteins into the ER in the presence of brefeldin A suggests an ER recycling pathway. Cell 60:821-836.

Martin N, Jaubert J, Gounon P, Salido E, Haase G, Szatanik M, Guenet JL (2002) A missense mutation in Tbce causes progressive motor neuronopathy in mice. Nat Genet 32:443-447.

Mimori-Kiyosue Y, Grigoriev I, Lansbergen G, Sasaki H, Matsui C, Severin F, Galjart N, Grosveld F, Vorobjev I, Tsukita S, Akhmanova A (2005) CLASP1 and CLASP2 bind to EB1 and regulate microtubule plus-end dynamics at the cell cortex. J Cell Biol 168:141-153.

Mitsumoto H, Bradley WG (1982) Murine motor neuron disease (the wobbler mouse): degeneration and regeneration of the lower motor neuron. Brain 105:811-834.

Mitsumoto H, Gambetti P (1986) Impaired slow axonal transport in wobbler mouse motor neuron disease. Ann Neurol 19:36-43.

Nakamura N, Rabouille C, Watson R, Nilsson T, Hui N, Slusarewicz P, Kreis TE, Warren G (1995) Characterization of a cis-Golgi matrix protein, GM130. J Cell Biol 131:1715-1726.

Parvari R, Hershkovitz E, Grossman N, Gorodischer R, Loeys B, Zecic A, Mortier G, Gregory S, Sharony R, Kambouris M, Sakati N, Meyer BF, Al Aqeel AI, Al Humaidan AK, Al Zanhrani F, Al Swaid A, Al Othman J, Diaz GA, Weiner R, Khan KT, Gordon R, Gelb BD (2002) Mutation of TBCE causes hypoparathyroidism-retardation-dysmorphism and autosomal recessive Kenny-Caffey syndrome. Nat Genet 32:448-452.

Parvari R, Diaz GA, Hershkovitz E (2007) Parathyroid development and the role of tubulin chaperone E. Horm Res 67:12-21.

Pasinelli P, Brown RH (2006) Molecular biology of amyotrophic lateral sclerosis: insights from genetics. Nat Rev Neurosci 7:710-723.

Perrin FE, Boisset G, Lathuiliere A, Kato AC (2006) Cell death pathways differ in several mouse models with motoneurone disease: analysis of pure motoneurone populations at a presymptomatic age. J Neurochem 98:1959-1972.

Puls I, Jonnakuty C, LaMonte BH, Holzbaur EL, Tokito M, Mann E, Floeter MK, Bidus K, Drayna D, Oh SJ, Brown Jr RH, Ludlow CL, Fischbeck KH (2003) Mutant dynactin in motor neuron disease. Nat Genet 33:455-456.

Pun S, Santos AF, Saxena S, Xu L, Caroni P (2006) Selective vulnerability and pruning of phasic motoneuron axons in motoneuron disease alleviated by CNTF. Nat Neurosci 9:408-419.

Raoul C, Estevez AG, Nishimune H, Cleveland DW, deLapeyriere O, Henderson CE, Haase G, Pettmann B (2002) Motoneuron death triggered by a specific pathway downstream of Fas. Potentiation by ALS-linked SOD1 mutations. Neuron 35:1067-1083.

Ravula SK, Wang MS, McClain MA, Asress SA, Frazier B, Glass JD (2007) Spatiotemporal localization of injury potentials in DRG neurons during vincristine-induced axonal degeneration. Neurosci Lett 415:34-39.

Richmond FJ, Gladdy R, Creasy JL, Kitamura S, Smits E, Thomson DB (1994) Efficacy of seven retrograde tracers, compared in multiplelabelling studies of feline motoneurones. J Neurosci Methods 53:35-46.

Rios RM, Sanchis A, Tassin AM, Fedriani C, Bornens M (2004) GMAP-210 recruits gamma-tubulin complexes to cis-Golgi membranes and is required for Golgi ribbon formation. Cell 118:323-335.

Sagot Y, Tan SA, Baetge E, Schmalbruch H, Kato AC, Aebischer P (1995a) Polymer encapsulated cell lines genetically engineered to release ciliary neurotrophic factor can slow down progressive motor neuronopathy in the mouse. Eur J Neurosci 7:1313-1322.

Sagot Y, Duboisdauphin M, Tan SA, Debilbao F, Aebischer P, Martinou JC, Kato AC (1995b) Bcl-2 overexpression prevents motoneuron cell body 
loss but not axonal degeneration in a mouse model of a neurodegenerative disease. J Neurosci 15:7727-7733.

Sapperstein SK, Walter DM, Grosvenor AR, Heuser JE, Waters MG (1995) p115 is a general vesicular transport factor related to the yeast endoplasmic reticulum to Golgi transport factor Usolp. Proc Natl Acad Sci USA 92:522-526.

Schmalbruch H, Jensen HS, Bjaerg M, Kamieniecka Z, Kurland L (1991) A new mouse mutant with progressive motor neuronopathy. J Neuropathol Exp Neurol 50:192-204.

Schmitt-John T, Drepper C, Mussmann A, Hahn P, Kuhlmann M, Thiel C, Hafner M, Lengeling A, Heimann P, Jones JM, Meisler MH, Jockusch H (2005) Mutation of Vps54 causes motor neuron disease and defective spermiogenesis in the wobbler mouse. Nat Genet 37:1213-1215.

Seemann J, Jokitalo E, Pypaert M, Warren G (2000) Matrix proteins can generate the higher order architecture of the Golgi apparatus. Nature 407:1022-1026.

Sendtner M, Schmalbruch H, Stöckli KA, Carroll P, Kreutzberg GW, Thoenen H (1992) Ciliary neurotrophic factor prevents degeneration of motor neurons in mouse mutant progressive motor neuronopathy. Nature 358:502-504.

Silva A, Wang Q, Wang M, Ravula SK, Glass JD (2006) Evidence for direct axonal toxicity in vincristine neuropathy. J Peripher Nerv Syst $11: 211-216$.

Simonin Y, Perrin FE, Kato AC (2007) Axonal involvement in the Wlds neuroprotective effect: analysis of pure motoneurons in a mouse model protected from motor neuron disease at a pre-symptomatic age. J Neurochem 101:530-542.

Terada S, Kinjo M, Hirokawa N (2000) Oligomeric tubulin in large transporting complex is transported via kinesin in squid giant axons. Cell 103:141-155.

Tian G, Huang Y, Rommelaere H, Vandekerckhove J, Ampe C, Cowan NJ (1996) Pathway leading to correctly folded beta-tubulin. Cell 86:287-296.

Tian G, Lewis SA, Feierbach B, Stearns T, Rommelaere H, Ampe C, Cowan NJ (1997) Tubulin subunits exist in an activated conformational state generated and maintained by protein cofactors. J Cell Biol 138:821-832.

Tian G, Huang MC, Parvari R, Diaz GA, Cowan NJ (2006) Cryptic out-offrame translational initiation of TBCE rescues tubulin formation in com pound heterozygous HRD. Proc Natl Acad Sci USA 103:13491-13496.

Wang W, Ding J, Allen E, Zhu P, Zhang L, Vogel H, Yang Y (2005) Gigaxonin interacts with tubulin folding cofactor B and controls its degradation through the ubiquitin-proteasome pathway. Curr Biol 15:2050-2055.

Watson DF, Hoffman PN, Griffin JW (1990) The cold stability of microtubules increases during axonal maturation. J Neurosci 10:3344-3352.

Yamanaka K, Miller TM, McAlonis-Downes M, Chun SJ, Cleveland DW (2006) Progressive spinal axonal degeneration and slowness in ALS2deficient mice. Ann Neurol 60:95-104.

Zenker W, Hohberg E (1973) A-alpha-nerve-fiber: number of neurotubules in the stem fibre and in the terminal branches. J Neurocytol 2:143-148. 